\title{
The Growth of Local White Muscovy during Starter and Grower Periods
}

\author{
Susanti T, Purba M \\ Indonesian Research Institute for Animal Production, PO Box 221, Ciawi, Bogor \\ E-mail: triana_susie@yahoo.com
}

(received 10-03-2017; revised 26-06-2017; accepted 27-06-2017)

\begin{abstract}
ABSTRAK
Susanti T, Purba M. 2017. Pertumbuhan entog putih lokal periode starter dan grower. JITV 22(2): 63-67. DOI: http://dx.doi.org/10.14334/jitv.v22i2.1615

Ternak dengan pertumbuhan relatif cepat dan bobot badan yang besar memiliki potensi sebagai penghasil daging. Di Indonesia, entog lokal, terutama yang berbulu putih, merupakan salah satu ternak penghasil daging. Namun analisis terhadap pertumbuhannya masih jarang dilakukan. Oleh karena itu, tujuan penelitian ini adalah untuk menentukan titik infleksi sebagai peubah pertumbuhan, sehingga mempermudah penyusunan program pengembangan entog putih lokal. Sebanyak 168 ekor entog putih unsex diamati pertumbuhannya sejak umur DOD sampai 112 hari. Data pertumbuhan adalah bobot badan per individu yang diperoleh dari hasil penimbangan setiap 2 minggu. Analisa data dilakukan menggunakan kurva pertumbuhan model Gompertz. Hasil penelitian yang diperoleh adalah persamaan pertumbuhan entog putih lokal berdasarkan model Gompertz. Persamaan tersebut adalah $\mathrm{Y}=2591,3 * \exp (-3,8636 * \exp -0,0272 * \mathrm{t})$. Berdasarkan persamaan tersebut, titik infleksi entog putih lokal terjadi pada umur 50 hari dengan bobot 953,29 g. Pertambahan bobot badan maksimal yang dapat dicapai adalah 2591,30 g. Dari penelitian ini dapat disimpulkan bahwa pertumbuhan entog putih lokal relatif lambat, namun bobot badannya relatif tinggi.
\end{abstract}

Kata Kunci: Entog Putih Lokal, Pertumbuhan, Periode Starter, Periode Grower

\begin{abstract}
Susanti T, Purba M. 2017. The growth of local white muscovy growth during starter and grower periods. JITV 22(2): 63-67. DOI: http://dx.doi.org/10.14334/jitv.v22i2.1615

Livestock animals with relatively fast growth and great body weight are potential as a producer of meat. In Indonesia, the local muscovy, especially the feathered white is one of the meat-producing livestock. However, an analysis of the growth on local white muscovy is still rarely done. Therefore, the purpose of this study was to determine the point of inflection as growth variables, thus simplifying the preparation of development programs of local white muscovy. A total of 168 of the local unsex white muscovy were examined for their growth since the DOD until 112 days of age. The data of growth i.e. body weight individually examined in every two weeks. The data were analyzed using Gompertz model. The result obtained was the growth equation of local white Muscovy based on the model of Gompertz: Y=2591.3*exp (-3.8636*exp-0.0272*t). Based on these equations, the point of inflection of the local white muscovy occurred at the age of 50 days with a weight of $953.29 \mathrm{~g}$. The maximum body weight gain achieved was $2591.30 \mathrm{~g}$. It is conclude that the growth of local white muscovy was relatively slow, but the body weight was very heavy.
\end{abstract}

Key Words: Local White Muscovy, Growth, Starter Period, Grower Period

\section{INTRODUCTION}

Generally, local muscovy widely developed in Indonesia has various feather color of black and white. White muscovy relatively has high economy value in producing clean white meat as the preference of the consumer. White muscovy have the potential to be developed as meat-producing livestock.

Muscovy is well known as meat producer due to its relatively heavy body weight compared to other waterfowl. Baeza et al. (2002) reported that at 10 weeks of age, male muscovy was $1.700 \pm 101.55 \mathrm{~g} / \mathrm{head}$ of body weight with FCR value by $3.03 \pm 0.21$. Besides, the quality of muscovy meat is relatively unchanged on the population selected for body weight increases on 12 weeks of age. Even though, the muscovy have high potential of body weight, however its development program is rarely conducted, so it leads to decrease the population.

Growth is one of basic characteristic of biological system. It is an important characteristic that describe the genetic potential of an individual. Growth can be defined as the development of body size per time unit or also called as growth rate (Tompić et al. 2011). Based on the rate, the growth is divided into two phases: acceleration and retardation phases. On the acceleration phase, the growth is fast, so that the rate is high. In this case, metabolic process is more intensive than the catabolism. While, the growth on the retardation phase is slow due to the catabolism more active than the 
anabolism. Those two phases are bordered by inflection point which is a condition where the acceleration growth phase is stop and start to the retardation phase. Consequently, growth curve will be sigmoid with the inflation point that describes the highest growth rate (maximum) and the time of the puberty (Brody 1945; Sengul \& Kiraz 2005). Growth is highly influenced by species, breed and environment (Inounu et al. 2007).

Growth curve is very useful for analysis of production lifetime production efficiency which is useful for selection program to determine market strategy by optimizing the management and efficiency of livestock production related to body weight at the slaughtering age and feed management like administration of energy, protein and mineral at the right time (Vitezica et al. 2010; Darmani Kuhi et al.2010). A growth function must be able to describe data well and consisting of valuable biological parameter (France et al. 1996).

To describe sigmoid growth curve, non-linear regression can be used, such as Von Bertalanffy or Gompertz logistic model. A models to predict the growth pattern have been used on various different species: duck (Suparyanto et al. 2004; Schinckel et al. 2005; Vitezica et al. 2010), chicken (Rizzi et al. 2013), pig (Schinckel \& Craig 2002), Garut sheep (Inounu et al. 2007) and turkey (Porter et al. 2010). Among those models, Gompertz model has the highest accuracy and good biological interpretation, especially on presuming the point and value of inflection (Rizzi et al. 2013; Darmani Kuhi et al. 2010; Sengul \& Kiraz 2005; Nahashon et al. 2006; Roush et al. 2006). The evaluation of growth on body weight of local white muscovy starting from hatching to the adult age in this study used Gompertz model. The aim of this study was to determine the inflection point as growth variable of local white muscovy to do further breeding and raising program .

\section{MATERIALS AND METHODS}

The materials used in this study were 168 heads of unsexed local white muscovy. Those muscovy were confined in the same cage and feed conditions at the Indonesian Research Institute for Animal Production, Ciawi, Bogor. Brooder cages were used for the DOD until 4 weeks of age and litter by $1.5 \times 2.5 \mathrm{~m}$ cages with covered barn were used from 4 weeks to age of reproduction.

Observation and analysis were performed to body weight of muscovy on the starter and grower period during April to August 2015. Starter period was started from the day old duck (DOD) until 56 days. Meanwhile, grower period was started from 57 days to
112 days of age. Body weight was examined by weighing individually muscovy every week of starter period and every 2 weeks in the grower period.

Data analysis was conducted on age and body weight. Suparyanto et al. (2004) hypothesized the growth of duck using non-linear regression equation of Gompertz model by Marquardt procedure, which predicts easily the value on every iteration process can be determined easily.

The equationtion of Gompertz model was as follows:

$$
\mathrm{Y}=\mathrm{A}^{*} \operatorname{Exp}^{\left[-\mathrm{B}^{*} \operatorname{Exp}(-\mathrm{kt})\right]}
$$

where:

$\mathrm{A}=$ Body weight (asymptote), ie at the value of $\mathrm{t}$ approaching infinity.

Exp $=$ Basic logarithm (2,71828)

$k=$ Average growth rate until adult age.

$\mathrm{Y}=$ Animal body weight at $\mathrm{t}$ time

$\mathrm{t}=$ Time unit (day)

Statistical analysis was conducted using SAS program (2002). To obtain estimated value when the inflection point happen of a growth curve, it was used a equation of Blasco et al. (2002) who suggested said that inflection point is the second derivative of a nonlinear equation. The notation to estimate the inflection point of age was $t_{i}$ and for the inflection point of body weight was $y_{i}$. Its mathematical equation (Suparyanto et al. 2001) was:

$$
\begin{aligned}
& \mathrm{t}_{\mathrm{i}}=\ln \mathrm{B} / \mathrm{k} \\
& \mathrm{y}_{\mathrm{i}}=\mathrm{A} \mathrm{e}^{-1}
\end{aligned}
$$

Inflection point is maximum estimation point of life weight development. At that point, there is a shift in change from the growth acceleration to the retardation growth, which means a point where the animal experiences puberty (Brody 1945). The time of inflection is the most economic period, because at this point the mortality value is the lowest with fastest growth. Inflection point is difficult to be determined biologically, however, with the non-linear of growth curve it can be solved (Inounu et al. 2007).

\section{RESULT AND DISCUSSION}

Analysis results of body weight using the Gompertz equation and the value of each notation on that equation was presented in the Table 1 . Those notations consisted of asymptote value that means maximal life weight increase reachs by the white muscovy, the value of B as integral constantan and the value of $\mathrm{k}$ that showed growth rate to adult weight (Suparyanto et al. 2004). 
Table 1. Asymptote value (A), B and $k$ as growth variables of local white muscovy

\begin{tabular}{lc}
\hline \hline Variable & Value \\
\hline Asymptote (A) & $2591.30 \pm 75.0330$ \\
$\mathrm{~B}$ & $3.8636 \pm 0.1537$ \\
$\mathrm{~K}$ & $0.0272 \pm 0.00133$ \\
Equation & $\mathrm{Y}=2591.3 * \exp \left({ }^{-3.8636 * \exp -0.0272 * \mathrm{*}}\right)$ \\
\hline
\end{tabular}

Description:

$\mathrm{B}=$ integral constantan

$\mathrm{K}=$ parameter shows growth rate to the adult weight

According to the value of the growth variable, the growth equation of the local white muscovy was: $\mathrm{Y}=2591.3^{*} \exp \quad\left(-3.8636^{*} \exp -0.0272 * \mathrm{t}\right)$. Asymptote value means maximum llife weight gain that can be reach by the local muscovy. According to that asymptote value, a maximal body weight gained by the local muscovy was $2591.3 \mathrm{~g}$. This maximum body weight was relatively high compared to PMp duck that is also are the meat producer waterfowl. Susanti \& Prasetyo (2014) reported that maximum body weight of PMp duck was $2083.3 \mathrm{~g}$. However, the maximum body weight gain of local white muscovy was under the Peking duck by $3052.6 \mathrm{~g}$ (Susanti 2015). It is allegedly to be caused by the different waterfowl breed observed, because the A value is a property that is highly influenced by genetic factor (Brody 1945).

The $\mathrm{B}$ value was used to describe the relation of $\mathrm{Y0}$ (initial weight) and t, especially on the growth curve of the Brody model (Inounu et al. 2007). Meanwhile, on the other models such as Gompertz model is only as an integral constant. The $\mathrm{k}$ value is not a genetic affects, but highly affected by the environment. Inounu et al. (2007) suggested that $\mathrm{k}$ value for sheep is influenced by the year of born, the age of parent and breeding season.

The asymptote $\mathrm{B}$ and $\mathrm{k}$ values showed the variable growth was an inflection point consisting of the age and weight of inflection from the derivative of equation function of the Gompertz curve. According to the Gompertz curve, it was obtained that the age and weight were the inflection point values that was used to estimate growth rate of local white muscovy (Table 2).

Table 2. Weight and time of inflection, and growth rate of local white muscovy

\begin{tabular}{lc}
\hline \hline Variable & Value \\
\hline Inflection weight $(\mathrm{g})$ & 953.29 \\
Inflection age (day) & 50.00 \\
Growth rate (g/e/h) & 19.07 \\
\hline
\end{tabular}

Table 2, shows that inflection age of local white muscovy is 50 days with inflection weight of $953.29 \mathrm{~g}$. The inflection age was relatively slow compared to local ducks. Susanti \& Prasetyo (2014) reported that inflection age by 23 days for PMp duck as the meat producer duck, and 33 days for Alabio and Mojosari duck as layer duck, and 45.66 days for Peking duck (2015). Nahashon et al. (2006) reported that inflection age of mutiara chicken was 40.25 days for the male, and 40.18 days for the female. The infection weight of local white muscovy by $953.29 \mathrm{~g}$ was relatively heavy compared to inflection weight of Peking duck of $1122.99 \mathrm{~g}$ (Susanti 2015).

According to that inflection point, estimation of growth rate was $19.07 \mathrm{~g} / \mathrm{head} / \mathrm{day}$. The growth rate of local white muscovy was relatively slow compared to the PMp or Peking ducks as meat producing animals. Susanti \& Prasetyo (2014) reported the growth rate of PMp duck was $33.32 \mathrm{~g} /$ head/day. While, Susanti (2015) reported that growth rate of Peking duck was 24.60 g/head/day. Pingel (1993) suggested the selection of livestock animal that has a fast growth rate for optimum slaughtering weight in a relatively short period as expected by most farmers. Considering that fast growth livestock animals have good feed conversion and relatively low body fat content.

A determination value $\left(\mathrm{R}^{2}\right)$ showed a reliability of the an obtained model. The higher R2, the more the ability means the model to describe $\mathrm{Y}$ variable behavior (Mattjik \& Sumertajaya 2000). In this case, Y is a growth value of estimation according to Gompertz model. The $\mathrm{R}^{2}$ value in this study was 0.91079 and can be used to estimate a growth curve of local white muscovy according to Gompertz value.

The comparison of growth curve of Gompertz model and weighing data of this study is presented in the Figure 1. Figure 1 shows that growth curve estimation is sigmoid. There was a little difference in body weight at the beginning of growth, as shown that the body weight during day 1-7 was lighter than the Gompertz model. Whereas, the growth from the age of day 8 to 112 was similar.

\section{CONCLUSION}

High determination value $\left(\mathrm{R}^{2}\right)$ of 0.91079 proved that Gompertz model was able to predict the real growth of local white muscovy. The development of local white muscovy observed was relatively slow, but produced heavy body weight. Development of local white muscovy as meat producing animals obtained by crossing with other birds that have relatively fast growth, even though its body weight is relatively light. 


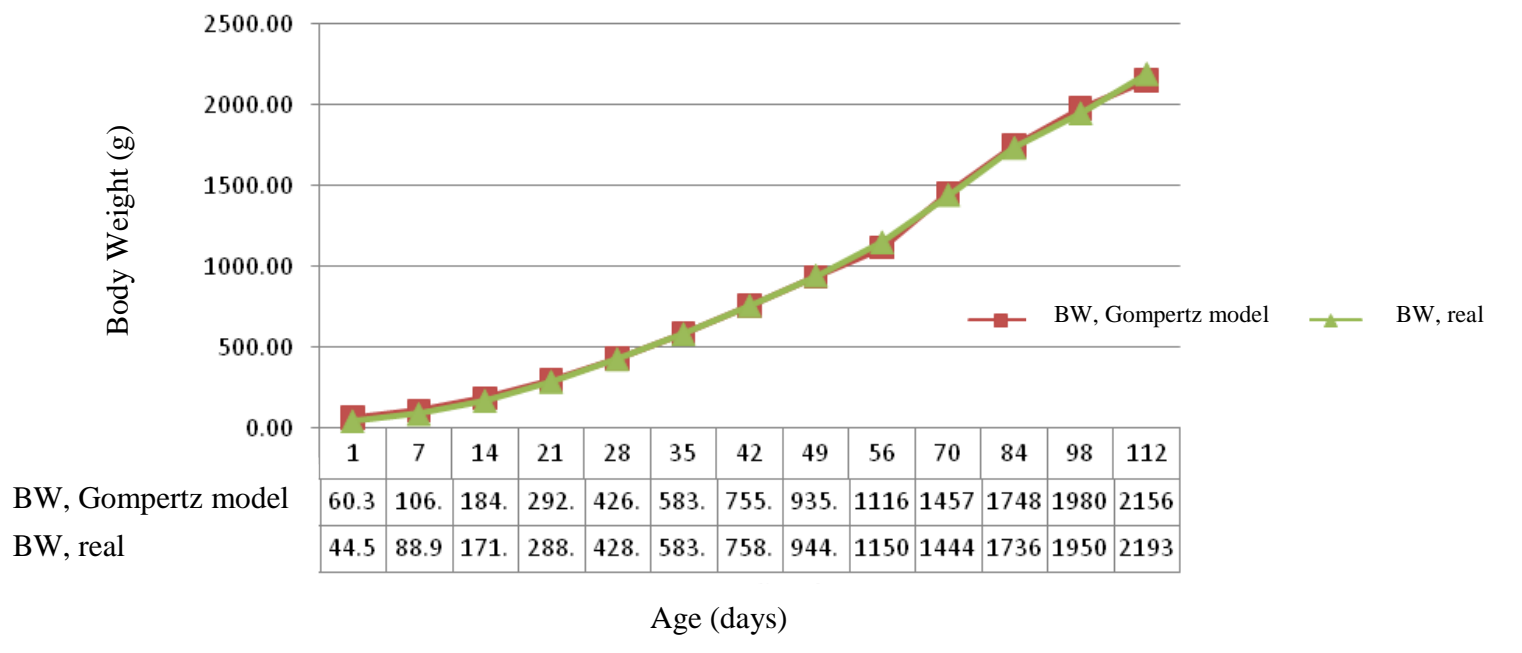

Figure 1. Growth rate of life body weight of local white muscovy in accordance to the Gompertz model and the real weighing data.

In accordance with the growth variables of local white muscovy, the inflection point at 50 days of age with body weight of $953.29 \mathrm{~g}$, the growth rate was 19.07 days. A maximal body weight gain can reached to $2591.30 \mathrm{~g}$.

\section{ACKNOWLEDGEMENT}

We are grateful to Dr. L. Hardi Prasetyo who provided guidance in this study. Also to the technicians of duck section: Miftah, Slamet Sumardi, Dedi Muslih, Riyanto, Hamdan, Saefulloh, and Ajum for their help in this study.

\section{REFERENCE}

Baeza E, Dessay C, Wacrenier N, Marche G, Listrat A. 2002. Effect of selection for improved body weight and composition on muscle and meat characteristics in Muscovy duck. Br Poult Sci. 43:560-568.

Brody S. 1945. Bioenergetics and growth. New York (USA). Reinhold Publishing Corporation.

Darmani Kuhi H, Porter T, Lopez S, Kebreab E, Strathe AB, Dumas A, Dijkstra J, France J. 2010. A review of mathematical functions for the analysis of growth in poultry. Poult Sci. 66:227-239.

France J, Dijkstra J, Dhanoa MS. 1996. Growth functions and their application in animal science. Ann Zootech. 45:165-174.

Inounu I, Mauluddin D, Noor RR, Subandriyo. 2007. Growth curve analysis of Garut sheep and its crossbreds. JITV. 12:286-299.

Mattjik AA, Sumertajaya M. 2000. Perancangan Percobaan dengan Aplikasi SAS dan MINITAB Jilid I. Bogor (Indones): IPB Press.
Nahashon SN, Aggrey SE, Adefope NA, Amenyenu A. 2006. Modeling growth characteristics of meat-type guinea fowl. Poult Sci. 85:943-946.

Pingel H. 1993. Genetics of growth and meat production in waterfowl. In: Poultry Breeding and Genetics. Crawford RD, editor. Saskatoon (Canada): Department of Animal and Poultry Science, University of Saskatchewan. p. 691-704.

Porter T, Kebreab, Darmani Kuhi H, Lopez S, Strathe AB, France J. 2010. Flexible alternatives to the Gompertz equation for describing growth with age in turkey hens. Poult Sci. 89:371-378.

Rizzi C, Contiero B, Cassandro M. 2013. Growth patterns of Italian local chicken populations. Poult Sci 92:22262235 .

Roush WB, Dozier WA, Branton SL. 2006. Comparison of Gompertz and Neural Network models of broiler growth. Poult Sci. 85:794-797.

[SAS] Statistical Analysis System. 2002. SAS/STAT, User's Guide, 9.0 version. Cary, NC, USA: SAS Institute Inc.

Schinckel AP, Adeola O, Einstein ME. 2005. Evaluation of alternative nonlinear mixed effects models of duck growth. Poult Sci. 84:256-264

Schinckel AP, Craig BA. 2002. Evaluation of alternative nonlinear mixed effects models of swine growth. Prof Anim Sci. 18:219-226.

Sengul T, Kiraz S. 2005. Non-linear models for growth curves in Large White turkeys. Turk J Vet Anim Sci. 29:331337.

Suparyanto A, Martojo H, Hardjosworo PS, Prasetyo LH. 2004. Kurva pertumbuhan morfologi itik betina hasil silang antara Pekin dengan Mojosari Putih. JITV. 9:8797. 
Suparyanto A, Subandriyo, Wiradarya TR, Martojo H. 2001. Analisis pertumbuhan non linier domba lokal Sumatera dan persilangannya. JITV. 6:259-264.

Susanti T. 2015. Analisis pertumbuhan empat rumpun itik dengan model gompertz. , penyunting. Prosiding Seminar Nasional Universitas Diponegoro. Semarang (Indones): Universitas Diponegoro.

Susanti T, Prasetyo LH. 2014. Pemanfaatan kurva pertumbuhan model Gompertz untuk membandingkan tipe itik. , penyunting. Prosiding Seminar Nasional
Peternakan Berkelanjutan 6. Bandung (Indones): Fakultas Peternakan, Universitas Padjadjaran.

Tompić T, Dobša J, Legen S, Tompić N, Medić H. 2011. Modeling the growth pattern of in-season and offseason Ross 308 broiler breeder flocks. Poult Sci. 90:2879-2887.

Vitezica ZG, Marie-Etancelin C, Bernadet MD, Fernandez X, Robert-Granie C. 2010. Comparison of nonlinear and spline regression models for describing mule duck growth curves. Poult Sci. 89:1778-1784. 